Association of Applied Biologists : Officers

THE following officers have been elected by the Association of Applied Biologists for the year 195859 : President, Dr. I. Thomas ; Vice-President, Miss A. P. Wilson; President-elect, Dr. R. V. Harris ; Treasurer, Dr. H. F. Barnes; General Secretary, Dr. L. Broadbent; Programme Secretary, Dr. W. G. Keyworth ; Editor, R. W. Marsh ; Assistant Editor, Dr. I. Thomas. The following new members of Council have also been elected : Dr. C. C. V. Batts, Prof. A. H. Bunting, Mr. J. Hobart and Dr. J. H. Western.

\section{Society for the Bibliography of Natural History}

The annual meeting of the Society for the Bibliography of Natural History was held at the Wellcome Historical Medical Library on March 24. The following elections were made: President, Dr. J. Ramsbottom; Hon. Secretary and Treasurer, A. C. Townsend (British Museum (Natural History), London, S.W.7) ; Committee, G. F. Elliott, Dr. F. C. Fraser, F. J. Griffin, W. T. Stearn, C. Kirke Swann, Dr. D. W. Tucker.

\section{Television Society Premiums}

Trre Television Society has made the following awards for outstanding papers read before it during 1956-57: The Wireless World Premium to Dr. D. Gabor (Imperial College of Science and Technology, London) for his paper on "A New Picture Tube"; The Mervyn Premium to Dr. E. L. C. White (E.M.I. Research Department) for his paper on "Alternatives to the N.T.S.C. Colour System"; The Mullard Premium to Mr. S. N. F. Doherty and Mr. P. L. Mothersole (Mullard Research Laboratories) for their paper on "Automatic Gain Control Circuits in Television Receivers"; The E.M.I. Premium to Dr. J. A. Saxton (Department of Scientific and Industrial Research, Radio Research Station) for his paper on "Scatter Propagation and its Application to Television"; The Electronic Engineering Premium to Dr. R. Pearce (E.M.I. Research Department) for his paper on "The Return of Electrostatic Focusing" ; and The Pye Premiumt o Mr. Ian Atkins (senior dramatic producer, B.B.C. Television) for his paper on "Studio Production Techniques".

\section{Announcements}

Dr. J. A. PopLe, of the University Chemical Laboratory, Cambridge, has been awarded the Faraday Society Marlow Medal and Prize for 1958 for his researches on electron structure of molecules, statistical mechanics and the electrical properties of gases, and nuclear magnetic resonance. The presentation of the Medal will be made at the annual general meeting of the Faraday Society to be held in Dublin in September.

Mr. A. D. McKnight, formerly Secretary of the Department of the Army, Melbourne, has been appointed full-time executive commissioner to the Australian Atomic Energy Commission. Sir Leslie Martin, professor of physics in the University of Melbourne and chairman of the Defence Research and Development Policy Committee, has been appointed part-time commissioner. The other commissioners are Prof. J. P. Baxter (chairman), Dr. H. G. Raggatt and Mr. H. M. Murray.

ON April 3 Mr. E. L. Mallalieu asked the President of the Board of Trade, in view of the public concern caused by his change of policy in appointing a
Comptroller-General of the Patent Office (see Nature, March 15, p. 725), whether he would institute an inquiry into the working of that Office between 1926 and the present time, and publish the results. In a written answer Sir David Eccles replied in the negative.

THE National Physical Laboratory, Teddington, will hold its annual open days on May 14 and 15, when the Laboratory will be on show to guests from industry, universities and government departments.

THE Eighth National Congress of Chemistry, organized by the Italian Chemical Society and the Society of Chemical Industry, will be held in Turin during May 27-June 2. Further information can be obtained from the Secretary, Society of Chemical Industry, 14 Belgrave Square, London, S.W.1.

A sYMPOSIUM on the "Chemistry of Co-ordination Compounds" will be held in December 1958, under the auspices of the National Acedemy of Sciences, India. Those wishing to attend or contribute are requested. to inform Dr. Arun K. Dey, Department of Chemistry, University of Allahabad, India, by June 30.

The Tenth International Congress of Genetics will be held at McGill University, Montreal, during August 20-27. There will be symposia on : structure of genetic material ; advances in human genetics; oytogenetics and plant breeding; genetics in animal breeding ; mutation and mutagenesis ; physiological genetics; genetics in evolution. Further information can be obtained from Dr. J. W. Boyes, Department of Genetios, McGill University, Montreal.

A Conference on the "Chemical and Physical Structure of Mucopolysaccharides" will be held on June 5 and 6 at Castle Hill, Ipswich, Mass. The conference is sponsored by the National Science Foundation and organized by the Retina Foundation. The proceedings will not be published. Besides the forty invited participants, only twenty additional scientists may attend because of the limitations of space and accommodation. Further information can be obtained from Dr. Endre A. Balazs or Dr. Roger Jeanloz (programme directors) at 30 Chambers Street, Boston 14, Mass.

A SUMMER school in programme design for automatic digital computing machines will be held in the University Mathematical Laboratory at Cambridge during September 15-26. It will be along similar lines to those held in previous years, but the material has been thoroughly revised and students will have access to EDSAC 2, a new and fast machine now installed in the Laboratory. Further information can be obtained from G. F. Hickson, Secretary of the Board of Extra-Mural Studies, Stuart House, Cambridge, to whom completed application forms should be returned not later than June 16 .

"Mrcro 58", an exhibition of photography with the microscope, will be held at the Polytechnic, Regent Street, London, W.1, during July 23-30. The Royal Microscopical Society extends an invitation to all photomicrographic workers to participate in this exhibition of photomicrographs, the first of what they hope will become an annual function. Series of micrographs, a coherent résumé of a study of a partioular problem, or related research exhibits will be acceptable. Further information can be obtained from R. Setterington, Hon. Secretary, "Micro 58", Royal Microscopical Society, Tavistock House South, Tavistock Square, London, W.C.1. 